\title{
面内せん断を受ける アルミニウム長方形板の耐荷カ
}

\author{
大倉 一郎 ${ }^{1}$. 寺川 勝大 ${ }^{2}$ \\ ${ }^{1}$ 正会員 大阪大学准教授 大学院工学研究科地球総合工学専攻（干565-0871 吹田市山田丘2-1） \\ E-mail: okura@civil.eng.osaka-u.ac.jp \\ 2 正会員 関西電力株式会社 北陸支社 新黒薙第二水力発電所工事所 \\ （一938-0281 黒部市宇奈月温泉町内山 2853）（研究当時大阪大学大学院工学研究科博士前期課程学生） \\ E-mail: terakawa.masahiro@a2.kepco.co.jp
}

\begin{abstract}
面内せん断を受けるアルミニウム長方形板の耐荷力を有限要素法による弾塑性有限変位解析によって明 らかにする．考慮するアルミニウム合金は，熱処理アルミニウム合金A6061-T6，A6005C-T5 と非熱処理ア ルミニウム合金A5083-Oである。解析においては，接合による残留応力と初期たわみ，さらに，6000系の 熱処理アルミニウム合金においては接合部の強度低下を考慮する．接合を有する6000系アルミニウム合金 の長方形板のせん断耐荷力の上限は，接合部の $0.2 \%$ $\%$ 断耐力であることを示す．解析結果に基づいて， 面内せん断を受ける長方形板の耐荷力曲線を与える.
\end{abstract}

Key Words : aluminum alloy plate, ultimate strength, shear, FSW, MIG welding, strength-reduction

\section{1. 序論}

これまでアルミニウム合金は橋の高欄や道路の防護柵 など付属品的な用途以外に土木構造物の主要部材として 用いられることはほとんどなかった。しかし，耐食性に 優れ，軽量であることから，2000年頃からアルミニウム 歩道橋や拡幅歩行者用アルミニウム床版が建設されるよ うになってきた1). 最近では道路橋用アルミニウム床版 を用いた鋼桁橋が建設されるようになってきている2). 道路橋用アルミニウム床版を支える鋼桁もアルミニウム 桁で製作することにより，メンテナンス・フリー橋が実 現され，さらなる軽量化により，橋の而震性の一層の向 上を図ることもできる.

現在建設されているアルミニウム歩道橋の設計は，道 路橋示方書 ${ }^{3)}$ と立体横断施設技術基準 ${ }^{4}$ に従い，アルミニ ウム合金の許容応力と製作はアルミニウム合金土木構造 物設計・製作指針案5) (以後，JAA指針と呼ぶ）に従っ ている. 図-1に示すように，アルミニウム合金桁の構造 は，鋼桁の構造と同じで，アルミニウム合金A5083-Oの 圧延板を用いたウェブとフランジがMIG溶接で連結され， さらに垂直補剛材と水平補剛材がウェブにMIG溶接で連 結される. しかし, 道路橋は歩道橋より規模が大きく, さらに道路橋の活荷重は歩道橋のそれより格段に大きく なるので，0.2\%耐力の低いA5083-Oで道路橋を設計する ことは困難である. したがって道路橋のアルミニウム合
金桁の設計には，0.2\%而力の高いA6061-T6，A6005C-T5 などの6000系アルミニウム合金の使用が必須である. し かし，これらの6000系アルミニウム合金は熱処理によっ て $0.2 \%$ 耐力が高められているので，MIG溶接を施すと接 合部の $0.2 \%$ 耐力が母材のそれの約半分まで低下する5). したがって，6000系アルミニウム合金で，図-1に示すよ うな桁を製作した場合，垂直補剛材が存在する位置で MIG溶接がウェブの一断面を横断するために，桁として の強度が低下する.

そこで，6000系アルミニウム合金を活かす桁構造とし て，図-2(a)に示すような，T型断面の押出形材を摩擦摚 拌接合(FSW $)^{1,6), 7)}$ によって突合せ接合し， ウェブの水平 方向に，等間隔に突起を配置したアルミニウム合金桁が 提案されている8).この桁構造にはウェブを鈆直方向に 横断する接合がないため, ウェブの一断面で強度が低下

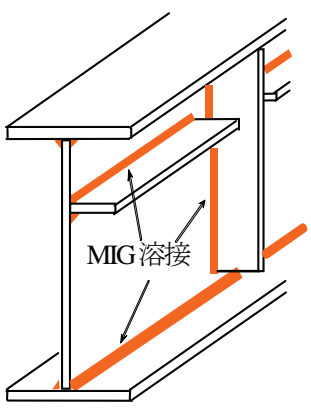

図-1 従来のアルミニウム合金桁 


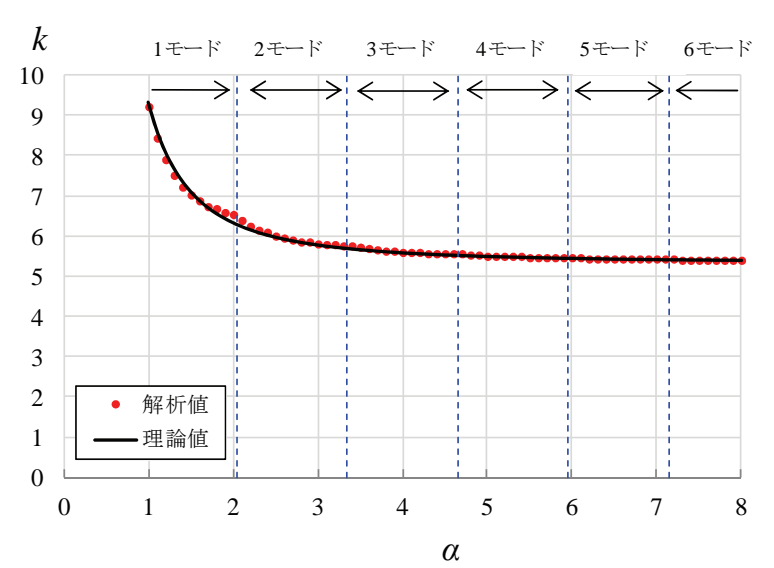

図-4 せん断座屈係数 $k$ と縦横比 $\alpha$ の関係

方向に強制変位させる. 表-1(c)は，左辺の鉛直変位と下 辺の水平変位をともに拘束し, 上辺を水平方向, 右辺を 鉛直方向に強制変位させる.

本章(2)節で述べる座屈解析により, 表-1に示寸三種類 の境界条件は同一のせん断座屈係数を与える ${ }^{16}$. したが って表-1(a)の境界条件Aに対して座屈解析を行う.

\section{（2）座屈解析}

面内せん断を受ける長方形板の座屈強度と座屈波形を 得るために, 汎用有限要素解析プログラムMARC ${ }^{17 を}$ 用 いて座屈解析を行う。有限要素として8節点アイソパラ メトリックシェル要素（MARCにおける要素番号22）を 用いる. MARCによる弹塑性有限変位解析において, 応 カ一ひずみ関係を線形とし，長方形板に初期たわみを与 えず，非正定值処理（NON-Positive Definition）を実行 しないことにより，全体剛性マトリックスの行列式

（Determinant）がゼロをとったときに生じるせん断応 力がせん断座屈強度である. 得られたせん断座屈強度を, 次式で定義される基本座屈応力 $\sigma_{e}$ で除してせん断座屈係 数 $k$ を得る.

$$
\sigma_{e}=\frac{\pi^{2} E}{12\left(1-\mu^{2}\right)}\left(\frac{t}{b}\right)^{2}
$$

$$
\begin{aligned}
\text { ここに, } & E \\
\mu & : \text { ヤング率 }(=70 \mathrm{GPa}) \\
b & : \text { 板幅 } \\
t & : \text { 板厚 }
\end{aligned}
$$

せん断座屈係数の精度と要素分割数の関係を調べた結 果 ${ }^{16}$, 有限要素の形状は正方形として, 板幅方向の要素

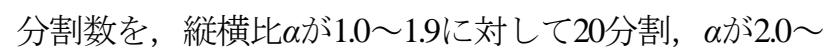

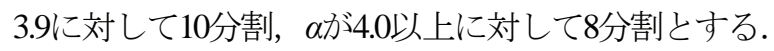

\begin{tabular}{|c|c|c|c|c|c|c|}
\hline \multirow{3}{*}{ 材料 } & \multirow{2}{*}{\multicolumn{2}{|c|}{ 母材 }} & \multicolumn{4}{|c|}{ 接合部 } \\
\hline & & & \multicolumn{2}{|c|}{ MIG溶接 } & \multicolumn{2}{|c|}{ 摩擦撹拌接合 (FSW) } \\
\hline & $\begin{array}{c}\sigma_{02} \\
(\mathrm{MPa})\end{array}$ & $n$ & $\begin{array}{c}\sigma_{02} \\
(\mathrm{MPa})\end{array}$ & $n_{j}$ & $\begin{array}{c}\sigma_{02} \\
(\mathrm{MPa})\end{array}$ & $n_{j}$ \\
\hline A6061-T6 & 245 & 29.1 & 108 & 5.3 & 108 & 10 \\
\hline A6005C-15 & 175 & 29.1 & 98 & 5.3 & 98 & 10 \\
\hline A5083-O & 127 & 5.3 & 127 & 5.3 & 127 & 5.3 \\
\hline
\end{tabular}

せん断座屈係数 $k$ と縦横比 $\alpha$ の関係を図-4 に示寸. 同 図には次式で与えられる算定值（ただし，図-4 では， 解析値と区別するためにこれを“理論值”と表記してい
表-2 $0.2 \%$ 耐力とひずみ硬化パラメータの值

る）も記載されている ${ }^{18)}$.

$$
k=5.34+\frac{4}{\alpha^{2}}
$$

解析值は，式(2)が与える算定值にほぼ一致する．図-4に 示寸，鉛直の破線を境としてせん断座屈波形のモード数 が変化する.

\section{3. 弾塑性有限変位解析}

\section{(1) 応カーひずみ関係}

面内せん断を受けるアルミニウム合金板の耐荷力を算 出するために, 次式で与えられる応力ーひずみ関係を使 用寸る ${ }^{19)}$.

[母材 $]$

$$
\left(\begin{array}{ll}
\varepsilon=\frac{\sigma}{E}+0.002\left(\frac{\sigma}{\sigma_{0.2}}\right)^{n} & \left(\sigma \leq \sigma_{0.2}\right) \\
\sigma=\sigma_{0.2} & \left(\sigma>\sigma_{0.2}\right)
\end{array}\right.
$$

[接合部 $]$

$$
\left(\begin{array}{ll}
\varepsilon=\frac{\sigma}{E}+0.002\left(\frac{\sigma}{\sigma_{j 0.2}}\right)^{n_{j}} & \left(\sigma \leq \sigma_{j 0.2}\right) \\
\sigma=\sigma_{j 0.2} & \left(\sigma>\sigma_{j 0.2}\right)
\end{array}\right.
$$

ここに,

$\varepsilon$ と $\quad$ :それぞれひずみと応力

$\sigma_{0.2}$ と $\sigma_{022}$ : それぞれ母材と接合部の0.2\%而力

$n$ そ $n_{j}$ ：それぞれ母材と接合部のひずみ硬化パラメー 夕

本研究では, 安全側に立って，0.2\%耐力以上のひずみ 硬化を考慮していない.

6000系アルミニウム合金A6061-T6とA6005C-T5，5000 系アルミニウム合金A5083-Oを扱う。これらのアルミニ ウム合金の $0.2 \%$ 耐力 $\sigma_{02}$ と $\sigma_{002}$, ひずみ硬化パラメータnと $n_{j}$ の值を表-2に示す. 母材と接合部の $0.2 \%$ 耐力に対して

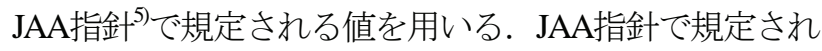
る接合部の $0.2 \%$ 耐力は, MIG溶接に対するものである. 


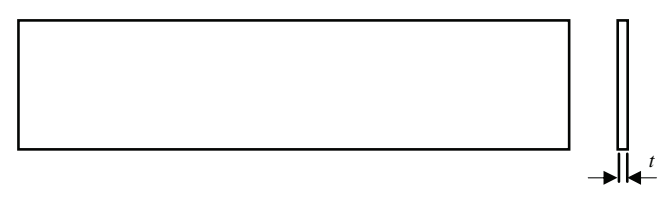

(a) 非接合板

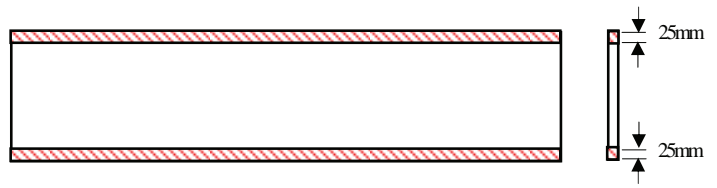

(b) 端部接合板（両縁 MIG 溶接）

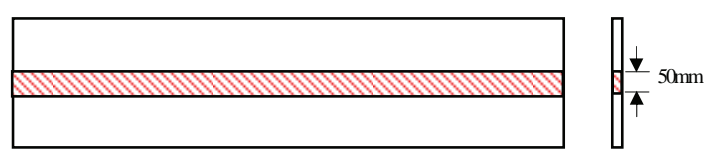

(c) 中央接合板（中央 FSW）

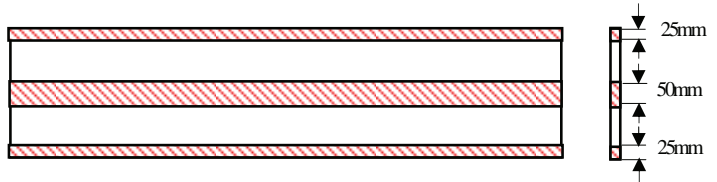

(d)

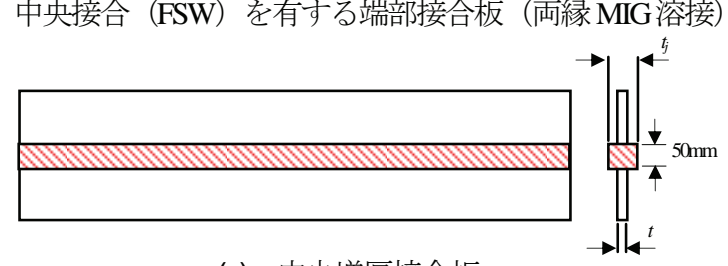

(e) 中央増厚接合板

図-5 接合位置と強度低下の範囲

摩擦擋挥接合はMIG溶接ほど入熱量が大きくないので, 摩擦擋汼接合部の $0.2 \%$ 耐力はMIG溶接部の $0.2 \%$ 耐力よ り高いと考えられる. しかし十分なデータがないので, 摩擦摚拌接合部の $0.2 \%$ 耐力に対して, JAA指針゙規定さ れるMIG溶接に対する值を採用する，他方，ひず夕硬化 パラメータ $n$ と $n_{j}$ の值は, 引張試験の結果に基づいて, 非超過確率5\%に対する值である

\section{（2）接合位置と強度低下の範囲}

アルミニウム長方形板の接合位置と強度低下の範囲を 図-5に示す，図-5(a)は，接合をもたない板，すなわち非 接合板である. 図-5(b)〜(e)は接合板であり，各図の斜線 は，6000系アルミニウム合金においては，摩擦摚汼接合 またはMIG溶接によって強度低下が生じる範囲を示す。

図-5(b)は，板の両縁をMIG溶接で隅肉溶接する場合で あり，強度低下が生じる範囲は板の各縁（溶接ルート）

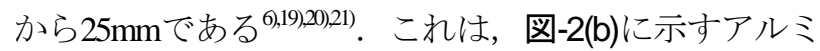
ニウム合金桁において, 桁高が低く, ウェブ内に摩擦擋 拌接合を必要としない場合に対応する.
図-5(c)は，板の中央を摩擦摚汼接合（FSW）で突合せ 接合する場合であり, 強度低下が生じる範囲は接合中心 から各側25mmで，計50mmである 6,199202,21)。これは，図2(a) に示すアルミニウム合金桁において，ウェブの中央 に摩擦擋找接合が存在する場合に対応する.

図-5(d)は，板の中央を摩擦擋拌接合で突合せ接合し， さらに板の両縁をMIG溶接で隅肉溶接する場合である.

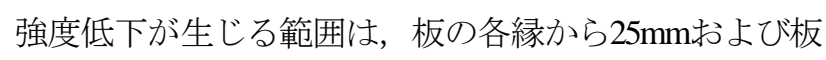
の中央に，接合中心から各側 $25 \mathrm{~mm}$ で, 計 $50 \mathrm{~mm}$ である. これは，図-2(b)のアルミニウム合金桁のウェブに対応す る.

図-5(e)は，接合部の強度低下を補うために，強度低下 を起こす範囲の板厚を厚くした接合板である. 押出形材 では，板の端を部分的に厚くすることは容易である．増 厚部の板厚は次式で与えられる.

$$
t_{j}=\frac{\sigma_{0.2}}{\sigma_{j 0.2}} t
$$

ここに， $t$ と $t_{j}$ : それぞれ母材の板厚と接合部の板厚 式(5)で与えられる板厚を接合部に与えることにより， $0.2 \%$ 耐力に関して, 接合部の断面強度は母材のそれと 同じになる.

本研究では, 隅肉溶接に対して, 溶接ルートから $25 \mathrm{~mm}$ の範囲, 摩擦摚挥接合による突合せ接合に対して, 溶接中心から各側 $25 \mathrm{~mm}$ の範囲が強度低下寸ることを仮 定しているので，接合板の板厚は $25 \mathrm{~mm}$ 以下としている. さらに本研究では, アルミニウム合金桁の製作方法とウ エブの板幅の関係 ${ }^{100}$ から, 接合板の板幅は $400 \mathrm{~mm}$ 以上と している.

\section{（3）初期たわみ}

押出形材を摩擦擋挥接合によって突合せ接合すること によって製作された，突起付きアルミニウム合金パネル の初期たわみが計測されている22. 初期たわみ形状は, 摩擦摚抖接合の方向, 寸なわち板の長手方向はサインの 1波が卓越し，摩擦摚拌接合の方向に対して直角な方向， すなわち板幅方向はサインの1波と3波が卓越している. そこで, 面内せん断を受ける長方形板に対して, 次の二 つの初期たわみ $w_{0}$ を仮定する.

$$
\begin{aligned}
& w_{0}=w_{0 \max } \sin \left(\frac{m \pi x}{a}\right) \sin \left(\frac{\pi y}{b}\right) \\
& w_{0}=w_{0 \max } \sin \left(\frac{\pi x}{a}\right) \sin \left(\frac{n \pi y}{b}\right)
\end{aligned}
$$

ここに,

$w_{0 \text { max }}$ : 最大初期たわみ

$m$ : 長方形板の長さ方向の初期たわみモード数

$n$ : 長方形板の板幅方向の初期たわみモード数 [式(3)で使用される母材のひずみ硬化パラ メータnとは異なることに注意 


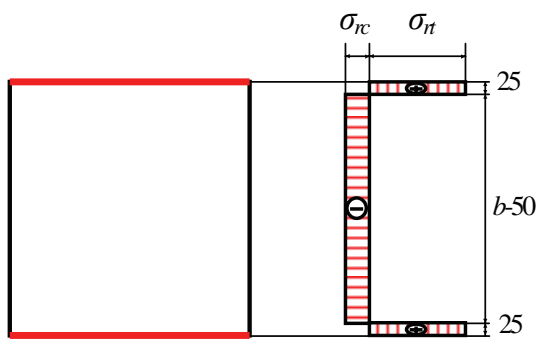

(a) 端部接合板

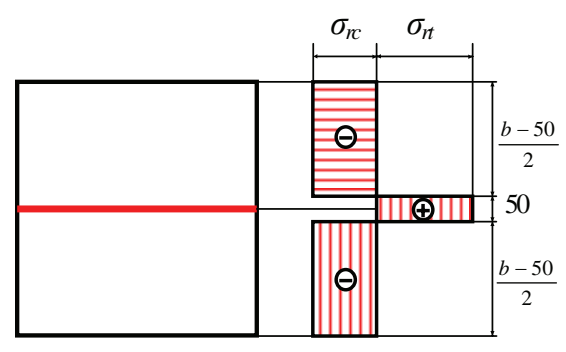

(b) 中央接合板

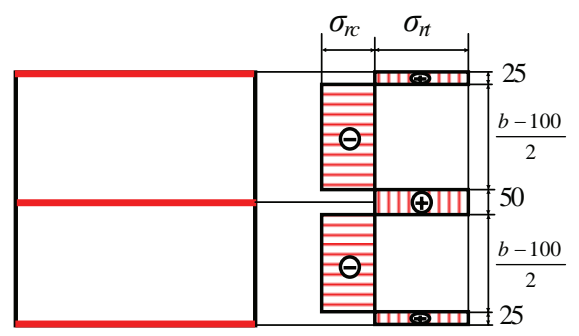

(c) 中央接合を有する端部接合板

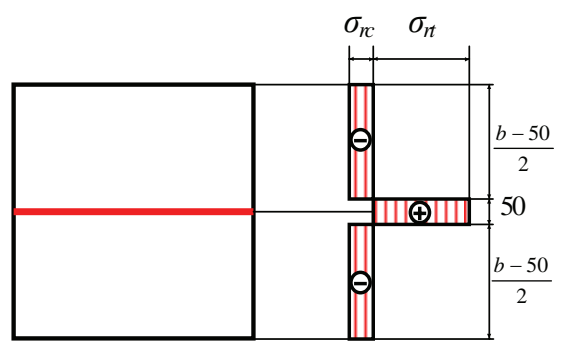

(d) 中央増厚接合板

図-6 残留応力分布

式(6)では，y軸方向のモード数を 1 とて，x軸方向のモ 一ド数を変える. 反対に，式(7)では， $x$ 軸方向のモード 数を1として，y軸方向のモード数を変える.

\section{（4）残留応力}

摩擦摚汼接合またはMIG溶接を用いて，突合せ接合に より製作される板に対して，接合線方向の残留応力は接 合中心から各側 $25 \mathrm{~mm}$ （6000系アルミニウム合金におい ては，接合による強度低下が生じる範囲と同じ）まで一 様な引張残留応力， $25 \mathrm{~mm}$ より離れた位置で一様な圧縮 残留応力となる矩形分布でモデル化され, 引張残留応力 の大きさは，最大で，接合部の $0.2 \%$ 耐力であることが
明らかにされている ${ }^{19)}$. これを考慮して，接合板の残留 応力分布に対する仮定を図-6に示す。

図-6(a)の端部接合板の場合, 各縁から $25 \mathrm{~mm} の$ 範囲が, $\sigma_{\mathrm{rt}}=\sigma_{002}$ の引張残留応力であり, それから離れた位置では $\sigma_{r c}=50 \sigma_{j 02} /(b-50)$ の土縮残留応力である. ここで, $b$ は板 幅であり, 単位はmmである。

図-6(b)の中央接合板の場合, 中央 $50 \mathrm{~mm}$ 範囲が, $\sigma_{\mathrm{rt}}=\sigma_{002}$ の引張残留応力であり, それから離れた位置では $\sigma_{r c}=50 \sigma_{j 02} /(b-50)$ の土縮残留応力である.

図-6(c)の中央接合を有する端部接合板の場合, 中央 $50 \mathrm{~mm}$ 範囲および各縁から $25 \mathrm{~mm}$ の範囲が， $\sigma_{\mathrm{r}}=\sigma_{002}$ の引 張残留応力であり, それから離れた位置では $\sigma_{r c}=100 \sigma_{002} /$ $(b-100)$ の圧縮残留応力である.

図-6(d)の中央増厚接合板の場合, 中央 $50 \mathrm{~mm} の$ 範囲が 式(5)で与えられる板厚に増厚され，この範囲に $\sigma_{r t}=\sigma_{002}$ の 引張残留応力が発生するので，これにつり合う圧縮残留 応力は $\sigma_{r c}=50 \sigma_{02} /(b-50)$ になる.

\section{（5）境界条件と要素分割}

汎用有限要素解析プログラムMARC ${ }^{17)}$ 用いて弾塑性 有限変位解析を行う。有限要素として8節点アイソパラ メトリックシェル要素（MARCにおける要素番号22）を 用いる. 表-1に示寸三種類の境界条件は同一のせん断耐 荷力を与えるので' を行う。この境界条件に対して, 長方形板の各辺に生じ るせん断応力の特性が文献16)に与えられている.

せん断耐荷力の精度と要素分割数の関係を調べた結 果 ${ }^{16}$, 非接合板に対して, 各有限要素の形状は正方形と して, 板幅方向の要素分割数を, $1.0 \sim 1.9 の \alpha に$ 対して10 分割, 2.0 以上の $\alpha$ に対して8分割とする. さらに接合板 に対して，各有限要素の形状は正方形として，接合部の 25mm幅に対して，1.0〜1.9のaに対して2要素，2.0以上の aに対して1要素となるように板幅全体を要素分割する.

\section{6000 系アルミニウム合金板のせん断耐荷力}

\section{（1）初期たわみ波形がせん断耐荷力に与える影響}

解析対象は, A6061-T6で, 縦横比 $\alpha=6.5$ の非接合板で ある、 x軸方向（板の長手方向）の初期たわみ形状がせ ん断而荷力に与える影響を図-7に示す。これは，初期た わみを与える式(6)において $m=1$ とに対する結果である。 $m=1$ は, 実際のパネルに生じる初期たわみの卓越波数で あり ${ }^{22)}, m=5$ は, 縦横比が $\alpha=6.5$ に対応する座屈モード数 である (図-4参照) 。最大初期たわみに対して, 両者と も $w_{0 \text { max }}=b / 250$ を仮定する. 図中の縦軸の $\tau_{u}$ は, 長方形板 の左右の辺上の節点に生じる $y$ 軸方向反力の合計を長方 形板の断面積で除した平均せん断応力で, 最大荷重に対 


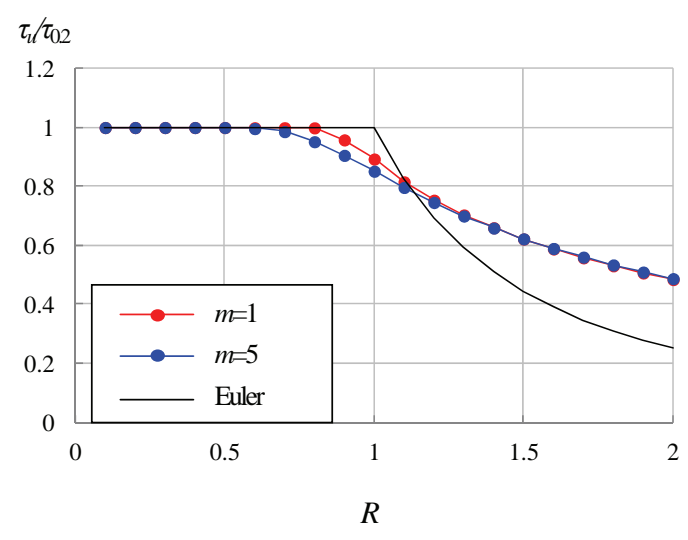

図-7 $x$ 軸方向の初期たわみ形状が せん断而荷力に与える影響

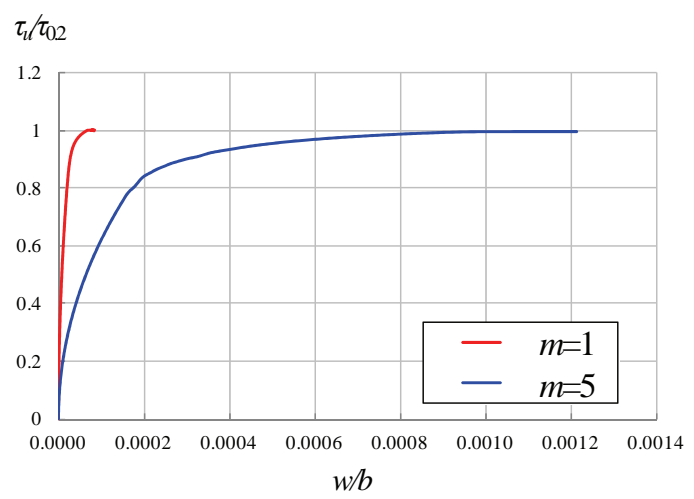

(a) $R=0.5$

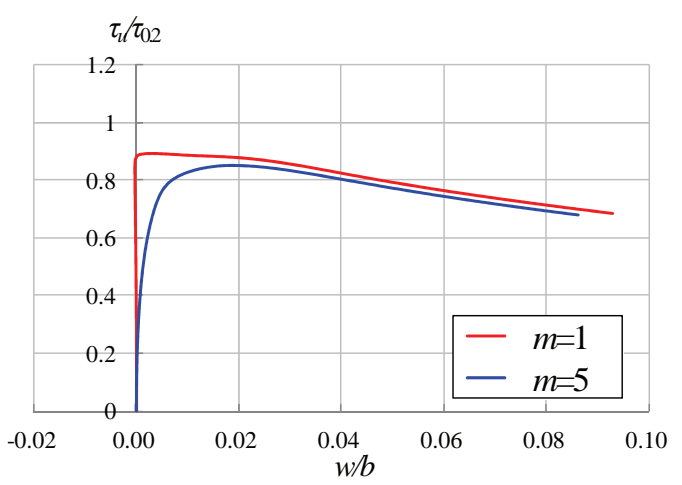

(b) $R=1.0$

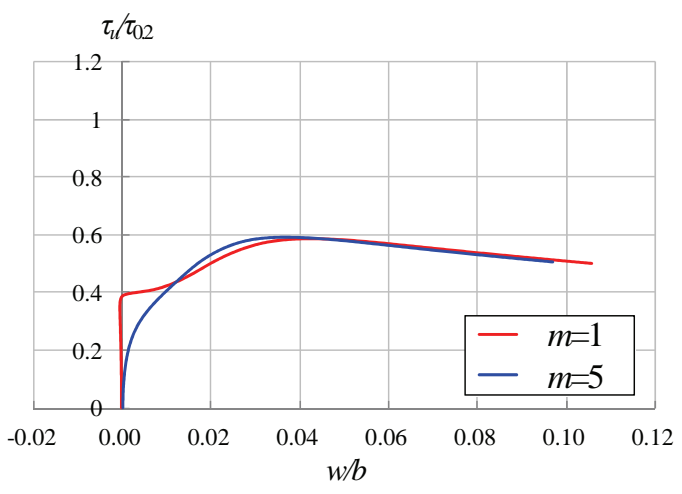

(c) $R=1.6$

図-8 荷重と面外変位の関係

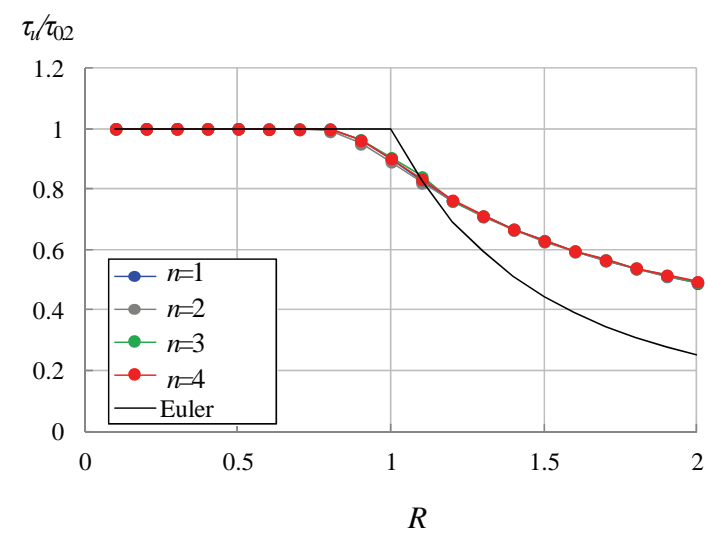

図-9 $y$ 軸方向の初期たわ多波形が せん断而荷力に与える影響

する值である.さらに， $\tau_{0.2}$ は次式で定義される母材の $0.2 \%$ せ断而讨力である.

$$
\tau_{0.2}=\frac{\sigma_{0.2}}{\sqrt{3}}
$$

他方， Rは，次式で定義される幅厚比パラメータである.

$$
R=\frac{1}{\pi} \sqrt{\frac{12\left(1-\mu^{2}\right)}{k}} \sqrt{\frac{\tau_{0.2}}{E}} \frac{b}{t}
$$

式(9)のkは，式(2)で与えられるせん断座屈係数である.

図-7から分かるように，Rが0.7から1.1の範囲で， $m=5$ に対するせん断而渮力が $m=1$ に対するそれより幾分低下 する. 幅厚比パラメータ $R=0.5,1.0,1.6$ に対する荷重と 面外変位の関係を図-8に示す. $w$ は板の中心 $(a / 2, b / 2)$ の 面外変位であり，板幅 $b$ 無次元化されている. 図-8(a) と(b)に示すように， $R=0.5$ と 1.0 の場合， $m=1$ の初期たわ みに対する $w / b$ は，最大荷重に達するまでほとんど増加 しないが， $m=5$ の初期たわみに対する $w / b$, 荷重の増 加に伴って増加し, 最大荷重に達する. 他方, 図-8(c)に 示すように, $R=1.6$ の場合， $m=1$ の初期たわみに対して, $\tau \tau_{0.2}$ が約 0.39 に達すると, $w / b か ゙$ 急激に増加し， $m=5$ の初期 たわみに対する面外変位に近づく．ここで， $\tau \tau_{02}=0.39$ は， $R=1.6 の$ 長方形板のせん断座屈強度に相当する.

$y$ 軸方向（板幅方向）の初期たわみ波形がせん断而嗬 力に与える影響を図-9に示す。これは，初期たわみを与 える式(7)において $n=1$ から4に対する結果である. 図から 分かるように, $n=1$ から4に対する初期たわみ波形に対し てせん断而渮力は一致する。したがって板幅方向の初期 たわみ波形がせん断而荷力に与える影響はない.

\section{（2）最大初期たわみがせん断耐荷力に与える影響}

最大初期たわみの大きさがアルミニウム長方形板のせ 儿断耐荷力に与える影響を図-10に示す. 解析対象は, A6061-T6で，縦横比 $\alpha=6.5$ の非接合板である. 図-10(a) と (b)は，式(6)の初期たわみに対して，それぞれm=1と5に 


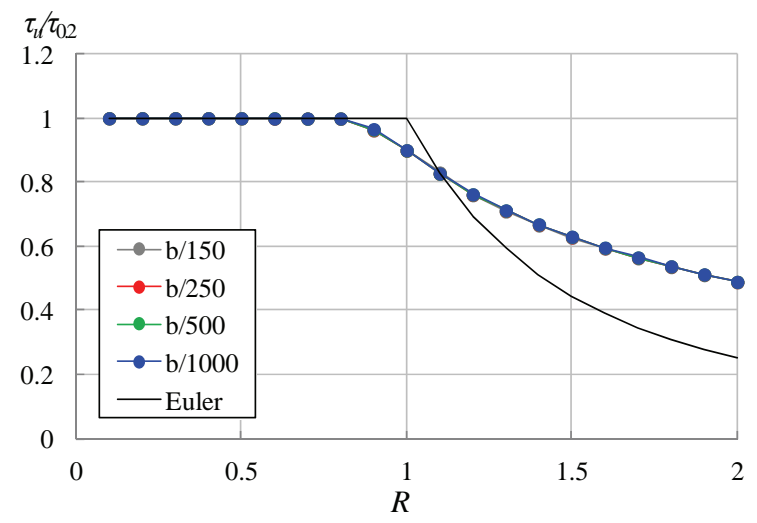

(a) $m=1$

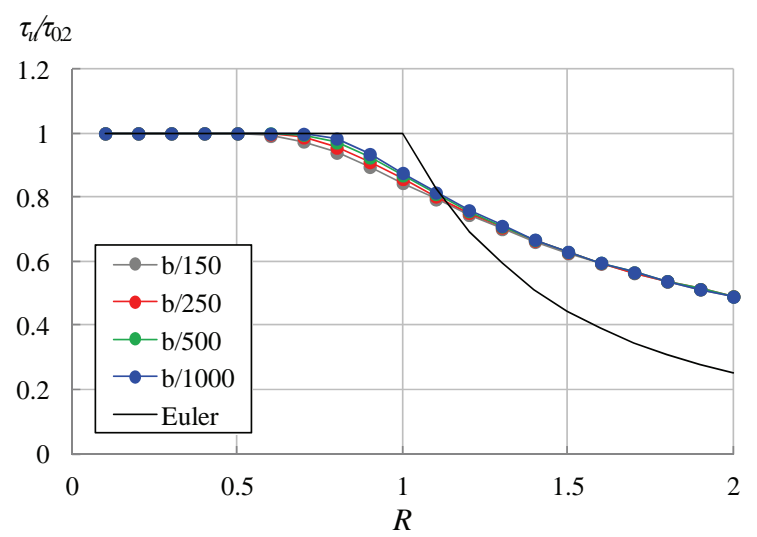

(b) $m=5$

図-10 最大初期たわみがせん断而荷力に与える影響

対する結果である．最大初期たわみ $w_{0 \text { max }}$ に対して，b/150, b/250，b/500，b/1000を仮定する．図-10(a)から分かるよ うに， $m=1$ の初期たわみに対して，最大初期たわみの大 きさが而何力に与える影響はほとんどない，他方，図10(b)から分かるように, $m=5$ の初期たわみに対して, $R$ が0.6から 1.10 範囲で, 最大初期たわみが大きくなると 而荷力がわずかに低下寸る.

\section{（3）接合部の強度低下と残留応力がせん断耐荷力に与 える影響}

図-5に示寸，接合部の強度低下がせん断而荷力に与え る影響を評価するために, 次の二つの強度低下評価モデ ルを設定する.

強度低下評価モデルM : MIG溶接部の応力ーひずみ関 係が長方形板の全領域に適用されたモデル。

強度低下評価モデルF : 摩擦摚抖接合部の応力ーひず み関係が長方形板の全領域に適用されたモデル。

解析対象は, A6061-T6で, 縦横比が $\alpha=6.5$ の端部接合 板, 中央接合板, 中央接合を有寸る端部接合板である. 初期たわみに対して式(6)を考慮し， $w_{0 \max }=b / 250$ として, $\alpha=6.5$ に対する座屈モード数5（図-4参照）を式(6)のmに

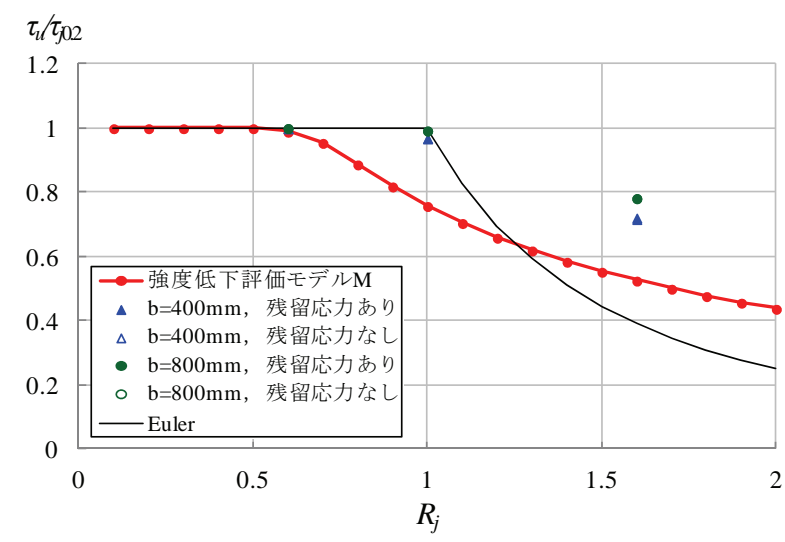

(a) 端部接合板（MIG 溶接）

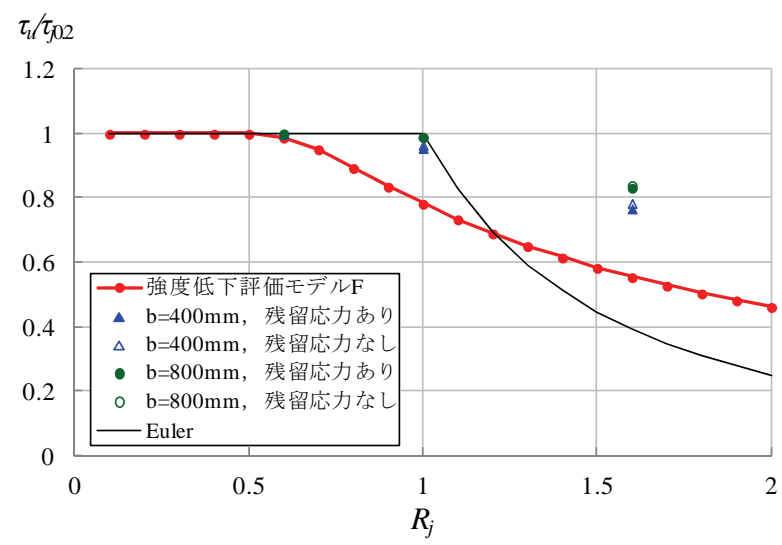

(b) 中央接合板（摩擦擋拌接合）

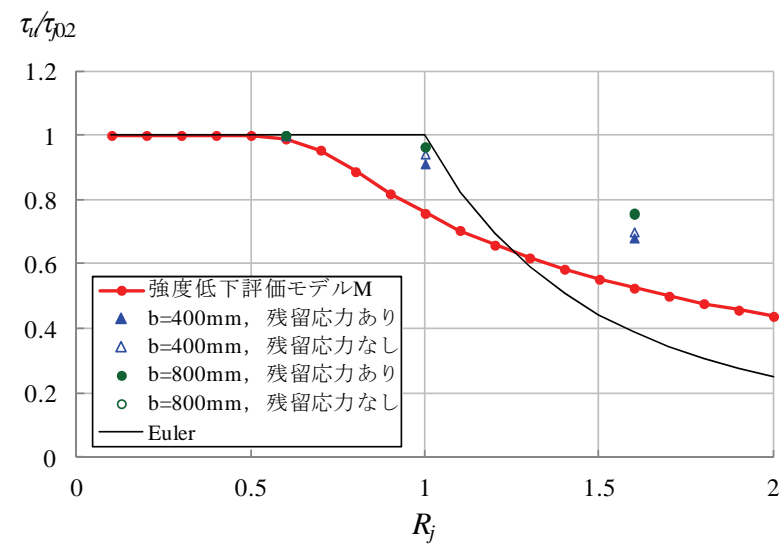

(c) 中央接合を有する端部接合板 (摩擦擋拌接合+MIG 溶接)

図-11 接合部の強度低下がせん断而荷力に与える影響

用いる. 残留応力の有無を考慮し，残留応力を考慮する 場合には，3 章(4)節の残留応力を各接合板に与える. 各 接合板の板幅に対して, $b=400 \mathrm{~mm}$ と $800 \mathrm{~mm}$ を考慮する.

端部接合板，中央接合板，中央接合を有する端部接合 板，さらに強度低下評価モデル $\mathrm{M}$ と $\mathrm{F}$ に対する $\tau_{l} / \tau_{02}-$ $R_{j}$ 関係を図-11 に示す．ここで， $\tau_{020}$ は次式で定義される 接合部の $0.2 \%$ せ断耐力である. 
表-3 A6061-T6の接合板の圧縮残留応力の值

\begin{tabular}{|c||c|c|}
\hline & 板幅 $b(\mathrm{~mm})$ & $\sigma_{r c} / \sigma_{0.2}$ \\
\cline { 2 - 3 } 端部接合板 & 400 & 0.063 \\
\hline \multirow{2}{*}{ 中央接合板 } & 800 & 0.029 \\
\cline { 2 - 3 } & 400 & 0.063 \\
\hline \multirow{2}{*}{ 中央接合を有する端部接合板 } & 800 & 0.029 \\
\cline { 2 - 3 } & 400 & 0.147 \\
\hline \multirow{2}{*}{ 中央増厚接合板 } & 800 & 0.063 \\
\cline { 2 - 3 } & 400 & 0.143 \\
\hline
\end{tabular}

$$
\tau_{j 0.2}=\frac{\sigma_{j 0.2}}{\sqrt{3}}
$$

さらに，R R は次式で定義される幅厚比パラメータである.

$$
R_{j}=\frac{1}{\pi} \sqrt{\frac{12\left(1-\mu^{2}\right)}{k}} \sqrt{\frac{\tau_{j 0.2}}{E}} \frac{b}{t}
$$

式(11)の $k$ は，式(2)で与えられるせん断座屈係数である.

図-11の各図から分かるように，板幅 $b$ が400mmと $800 \mathrm{~mm}$ に対する $\tau_{l} \tau_{j_{0.2}}$ の上限はともに 1 である.すなわち， 接合を有する長方形板のせん断而荷力の上限は，接合部 の0.2\%せん断耐力 $\tau_{j 02}$ である. 長方形板の板幅が小さく なるに従って，板幅に対して，接合部の幅が相対的に大 きくなるので，板幅が小さい長方形板のせん断而荷力は， 板幅が大きい長方形板のそれより低下し，強度低下評価

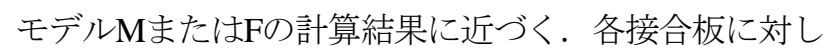
て強度低下評価モデルMまたはFの耐荷力が下限值を与 える.

他方, 図-11の各図から分かるように, 残留応力がせ 几断而何力に及ぼす影響は小さい. 引張残留応力と自己 平衡を取る圧縮残留応力を表-3 [同表には本章(4)節で述 べる中央増厚接合板に対する值も示してある〕に示す.

A6061-T6の接合板の $\sigma_{r d} / \sigma_{0.2}$ の值は，鋼の溶接板における, 降伏応力に対する圧縮残留応力の比 ${ }^{23)}$ と比較すると, 2 , 3倍小さい. このように，A6061-T6の接合板の場合，圧 縮残留応力が母材の $0.2 \%$ 耐力よりかなり小さいことが, 残留応力がせん断而荷力に及ぼす影響が小さいことの主 な理由と考えられる.

\section{（4） 中央増厚接合板のせん断耐荷力}

A6061-T6の中央増厚接合板の $\tau_{u} / \tau_{0.2}-R$ 関係を図-12に示 す. 縦横比 $\alpha=6.5$ であり，初期たわみに対して式(6)を考 慮し, $w_{0 \max }=b / 250$ として, 縦横比 $\alpha=6.5$ に対する座屈モ一 ド数5（図-4参照）を式(6)のmに使用している. 式(5)で 与えられる板厚を接合部に与える. 残留応力は考慮して ない，図から分かるように，中央増厚接合板のせん断耐 荷力は，非接合板のそれより増加し，板幅が大きくなる に従って，せん断耐荷力が非接合板のそれに近づく。こ れは，板幅が大きくなるに従って，板幅に対する増厚部

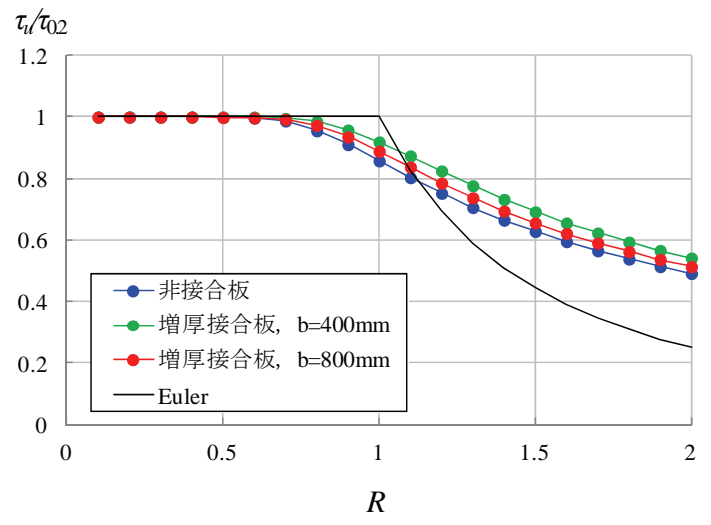

図-12 中央増厚接合板 $\tau_{l} / \tau_{02}-R$ 関係

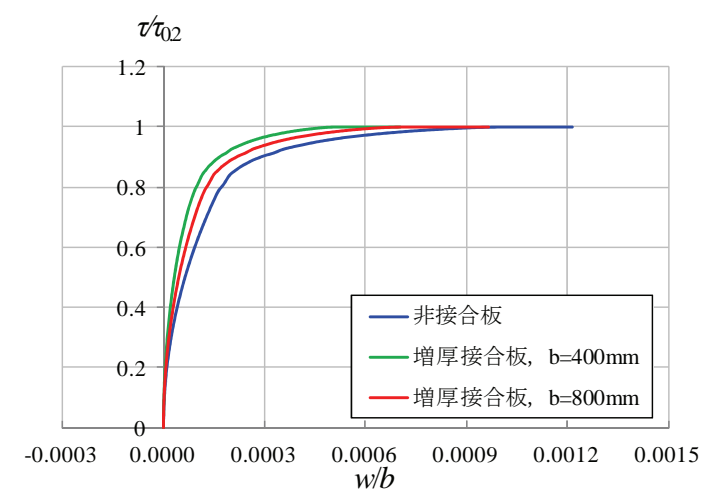

(a) $R=0.5$

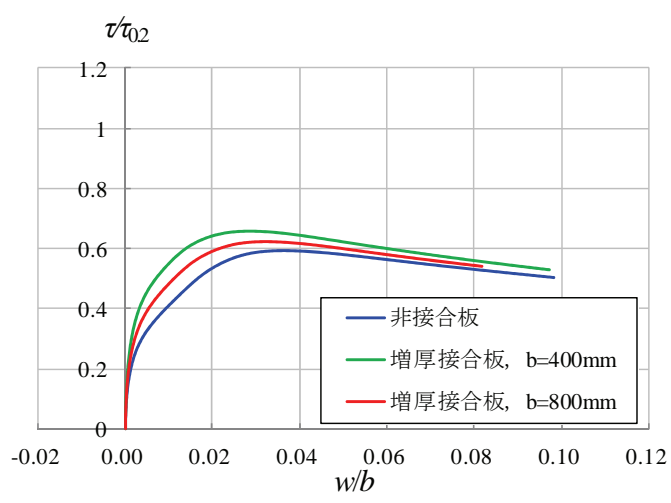

(b) $R=1.6$

図-13 中央増厚接合板の荷重と面外变位の関係

の幅が相対的に小さくなるからである．非接合板の耐荷 力が中央増厚接合板の下限值を与える.

中央増厚接合板の荷重と面外変位の関係を図-13に示 す. 長方形板の中心 $(a / 2, b / 2)$ の面外変位 $w$ が板幅 $b$ で無次 元化された值を横軸に採っている. 図-13(a)に示すよう に, $R=0.5$ の場合，非接合板と中央増厚接合板の面外変 位は異なるが，両者とも長方形板の全領域が塑性化する ことによって終局状態を迎えるため, 両者のせん断而荷 力は同じになる. 一方, 図-13(b)に示すように, $R=1.6$ の 場合，接合部が増厚されたことによる板曲げ岡性の増加 によって，面外変位が抑制されるので，中央増厚接合板 のせん断耐荷力は上昇する. 


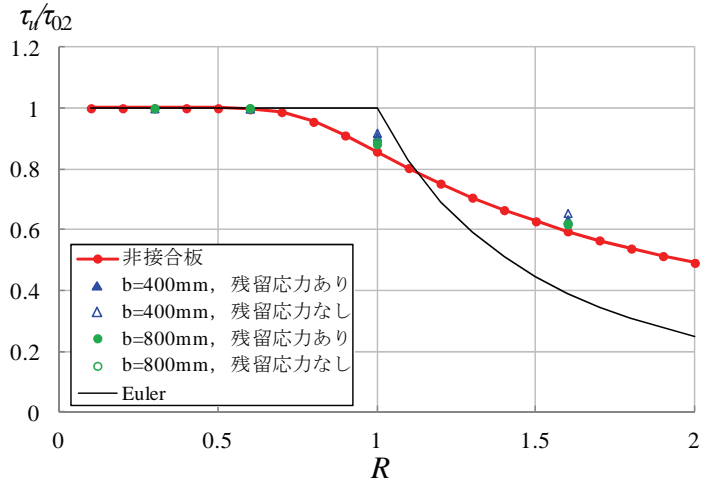

図-14 残留応力が中央増厚接合板の せん断而荷力に及ぼす影響

残留応力が中央増厚接合板のせん断而荷力に及ぼす影 響を図-14 に示寸. 残留応力がせん断而荷力に及ぼす影 響は小さい．これは，本章(3)節で述べたように， $\sigma_{r} / \sigma_{02}$ の值（表-3 参照）がかなり小さいことが主な理由と考 えられる。

中央増厚接合板のせん断而荷力は非接合板のそれより 大きくなることを示したが，Eurocode $9^{24}$ および米国ア

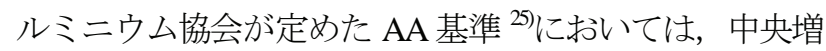
厚接合板は未だ考慮さていない.

\section{（5）A6061-T6板とA6005C-T5板の耐荷力の比較}

非接合板および強度低下評価モデル $\mathrm{M}$ と板に対し て，A6061-T6とA6005C-T5の耐荷力の比較を図-15に示す. 図-15(a)の非接合板に対して, 縦軸と横軸にそれぞれ $\tau_{l} / \tau_{02}$ とRが採られ, 図-15(b)の強度低下評価モデルMおよ び図-15(c)の強度低下評価モデルFに対して, 縦軸と横軸 にそれぞれて $/ \tau_{02}$ とR 兮採られている. 長方形板の綐横比 は $\alpha=6.5$ である. 式(6)の初期たわみを考慮し， $w_{0 \max }=b / 250$ として， $\alpha=6.5$ に対する座屈モード数 5 を式(6)のmに使用 している (図-4参照) . 各図加ら分かるように，無次元 表示された，A6061-T6板とA6005C-T5板の耐荷力はほぼ 一致する.

\section{（6） せん断耐荷力之縱横比の関係}

せん断而荷力と縦横比の関係を図-16に示寸。これは, A6061-T6の非接合板および同合金に対する強度低下評価 モデルMとFの結果である．式(6)の初期たわみを考慮し， $w_{0 \text { max }}=b / 250$ として, 長方形板の各縦横比に対する座屈モ 一ド数を式(6)のmに使用している (図-4参照) . 図-16(a) の非接合板に対して, 縦軸に $\tau_{u} / \tau_{02}$ が採られ, 幅厚比パラ メータにRが用いられている. 図-16(b)の強度低下評価モ デルMおよび図-16(c)の強度低下評価モデルFに対して, 縦軸に $\tau_{U} / \tau_{022}$ が採られ，幅厚比パラメータにR ている. $R$ とR $R_{j}$ ののせん断座屈係数 $k$ に対して式(2)が用 いられている.
土木学会論文集A1 (構造・地震工学), Vol. 69, No. 3, 491-504, 2013.

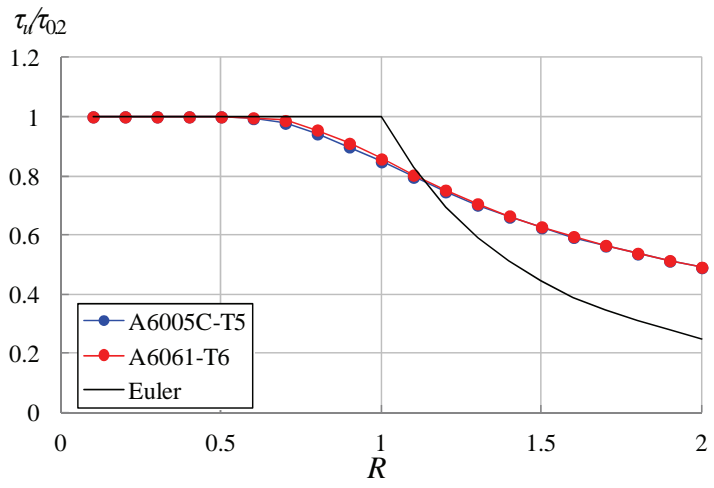

(a) 非接合板

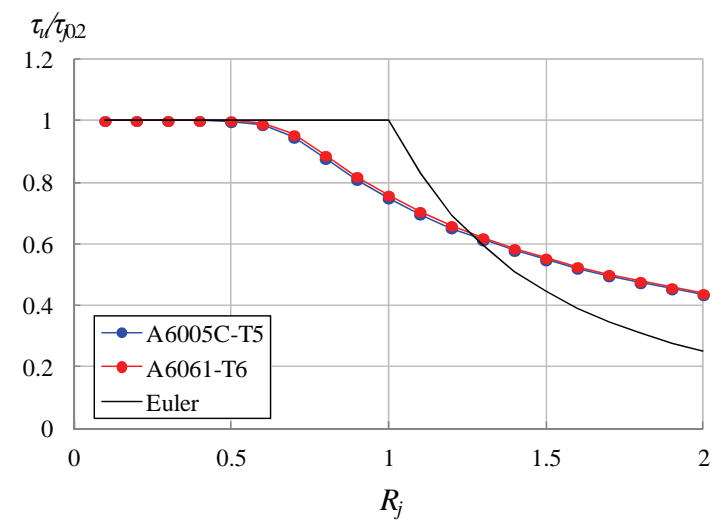

(b) 強度低下評価モデル $\mathrm{M}$

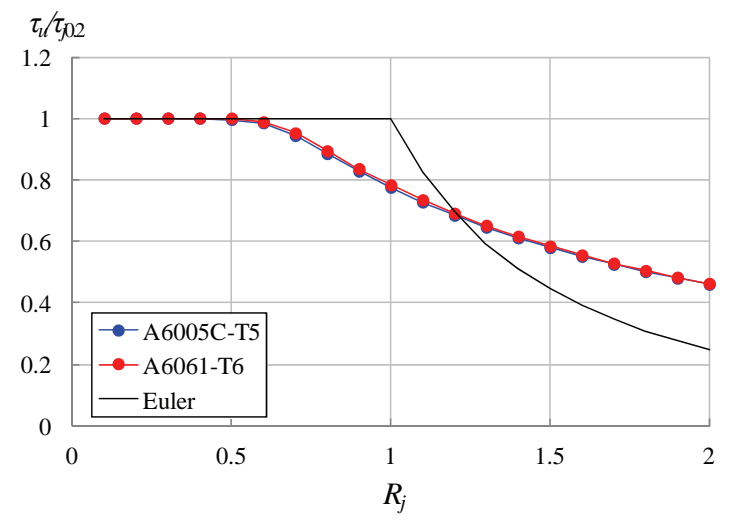

（c）強度低下評価モデル F

図-15 A6061-T6板と A6005C-T5板の せん断而荷力の比較

図-16の各図から分かるように, $R$ または $R_{j}$ の各值に対 して，せん断而渮力 $\tau_{l} / \tau_{02}$ または $\tau_{\downarrow} / \tau_{02}$ の值はほぼ一定であ る. したがって，式(9)で定義される幅厚比パラメータR および式(11)で定義される幅厚比パラメータ $R_{j}$ を用いる ことにより，これまで述べてきた $\alpha=6.5$ の長方形板に対 するせん断耐荷力は， $\alpha$ 五1.0以上の長方形板に対して適 用できる. 


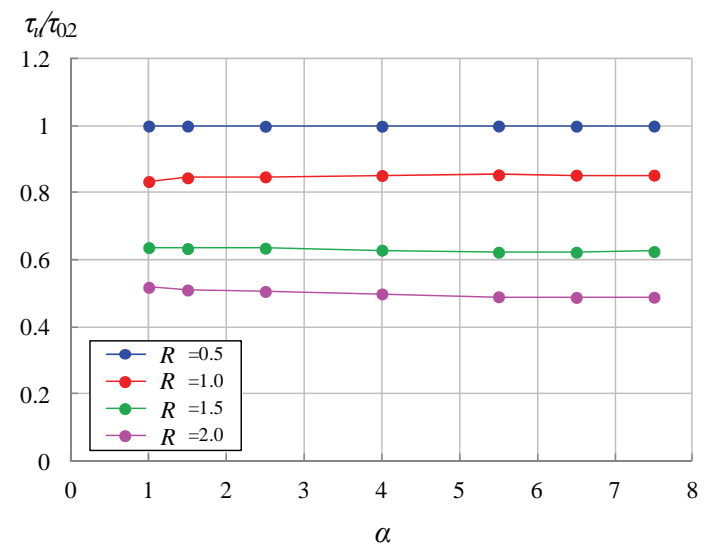

(a) 非接合板

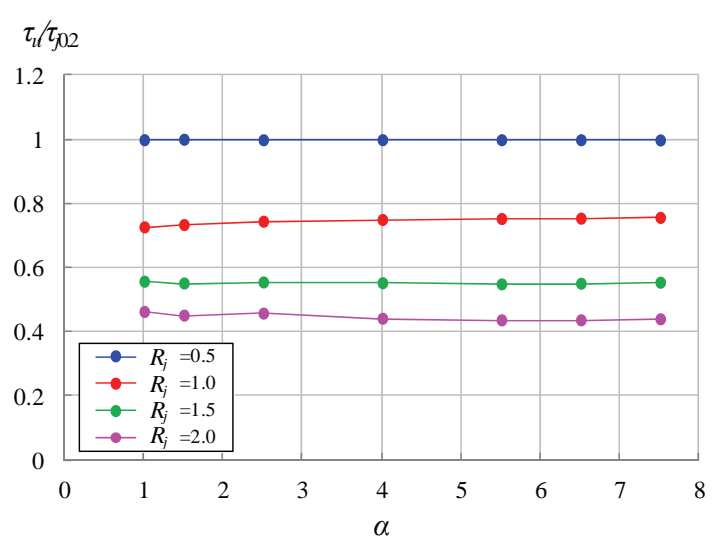

(b) 強度低下評価モデル $\mathrm{M}$

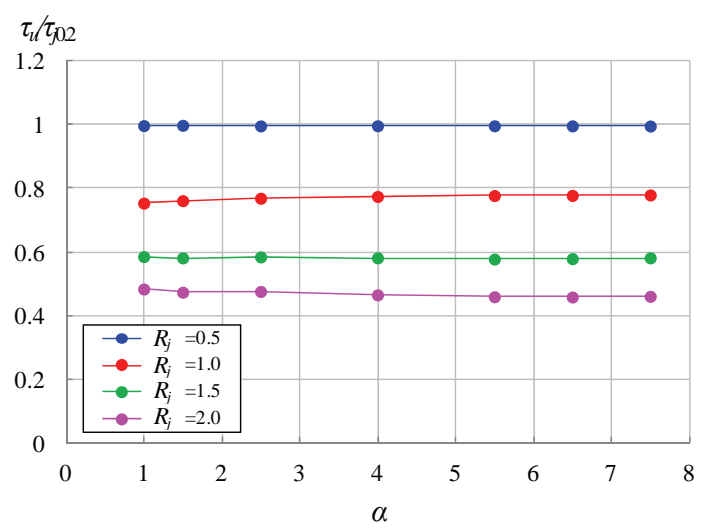

(c) 強度低下評価モデル F

図-16 A6061-T6板のせん断而荷力と縦横比の関係

\section{A5083-O板のせん断耐荷力}

\section{（1）残留応力がせん断耐荷力に与える影響}

A5083-Oの非接合板，端部接合板，中央接合板および 中央接合を有する端部接合板の $\tau_{u} / \tau_{0.2}-R$ 関係を図-17に示 す. 解析対象は, 縦横比が $\alpha=6.5$ の長方形板で, 式(6)の 初期たわみを考慮し， $w_{0 \max }=b / 250$ として，縦横比 $\alpha=6.5$ に 対する座屈モード数5を式(6)のmに使用している（図-4

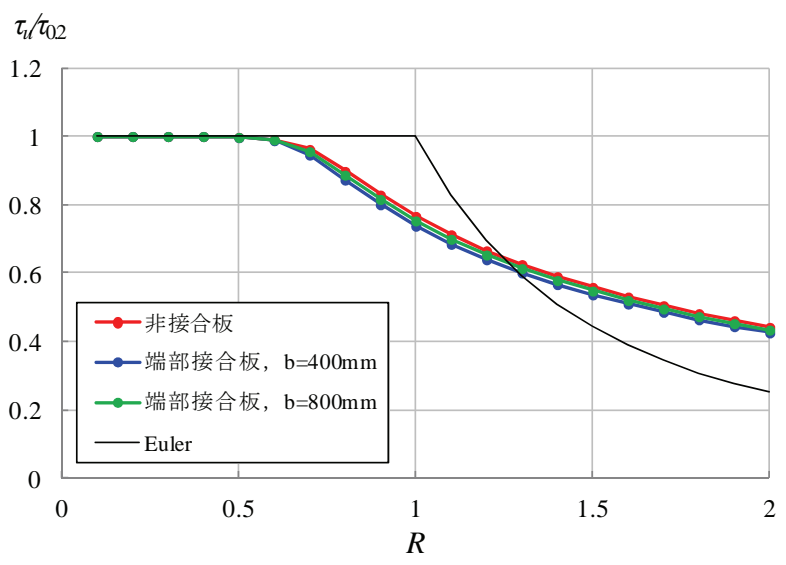

(a) 端部接合板

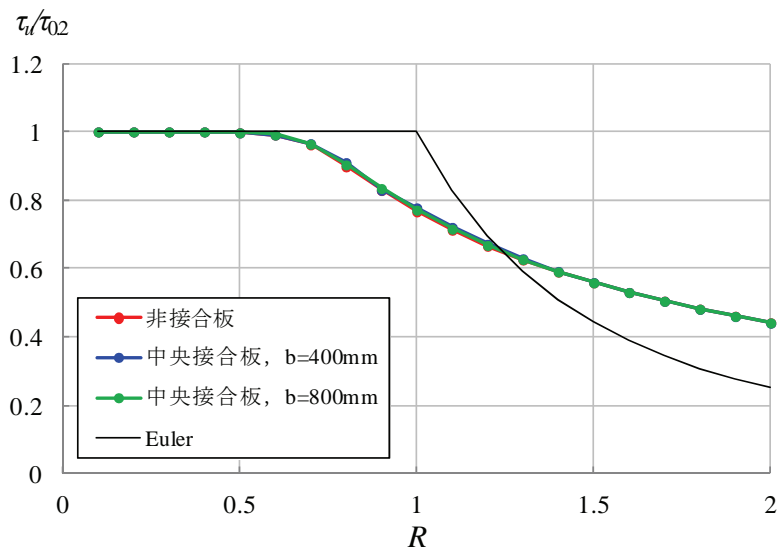

(b) 中央接合板

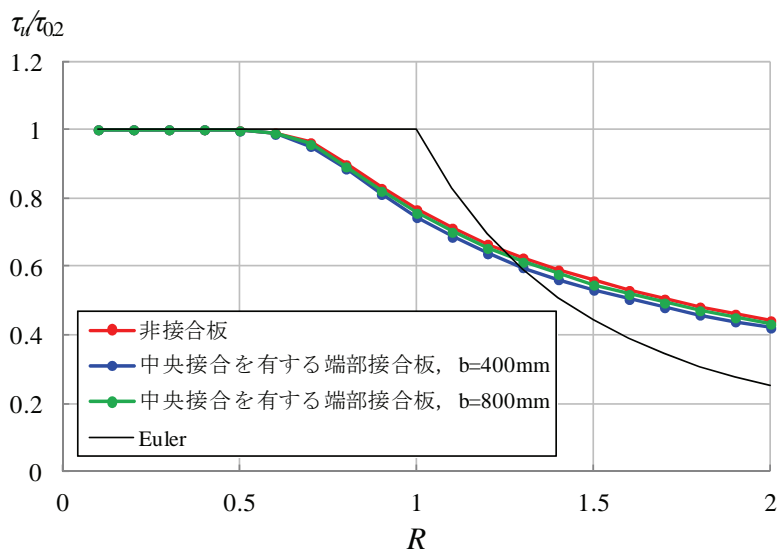

(c) 中央接合を有する端部接合板

図-17 A5083-O板の $\tau_{l} / \tau_{02}-R$ 関係

参照）. 各接合板の板幅に対して, $b=400 \mathrm{~mm}$ と $800 \mathrm{~mm}$ を考慮する. 3 章(4)節の残留応力を考慮する. 各図から 分かるように，残留応力が而荷力に与える影響は小さい. 引張残留応力と自己平衡を取る圧縮残留応力を表-4に 示す。同図から分かるように，A5083-O の接合板の $\sigma_{r d} / \sigma_{02}$ は，表-3 に示す A6061-T6 のそれより大きい. 式(3) が与える，A6061-T6 と A5083-O の応力ーひずタ関係を 図-18 に示寸. 同図から分かるように，A5083-O の応力 
表-4 A5083-O の接合板の圧縮残留応力の值

\begin{tabular}{|c||c|c|}
\hline & 板幅 $b(\mathrm{~mm})$ & $\sigma_{r c} / \sigma_{0.2}$ \\
\hline \hline \multirow{2}{*}{ 端部接合板 } & 400 & 0.143 \\
\cline { 2 - 3 } & 800 & 0.067 \\
\hline \multirow{2}{*}{ 中央接合板 } & 400 & 0.143 \\
\cline { 2 - 3 } & 800 & 0.067 \\
\hline \multirow{2}{*}{ 中央接合を有する端部接合板 } & 400 & 0.333 \\
\cline { 2 - 3 } & 800 & 0.143 \\
\hline
\end{tabular}

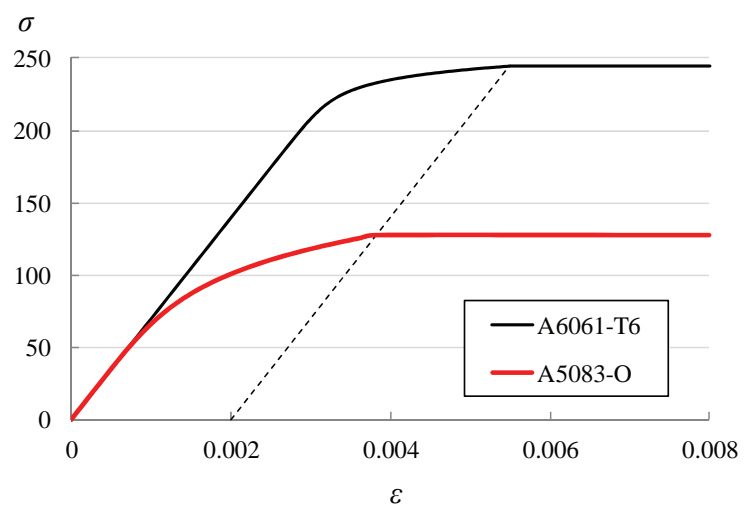

図-18 応力ーひずタ関係の比較

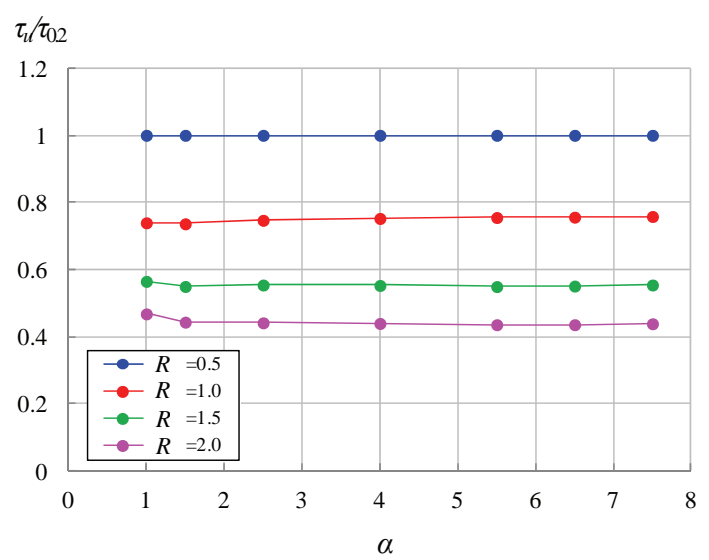

図-19 A5083-O板のせん断而荷力と縦横比の関係

一ひずみ関係は，0.2\%耐力に近づくに従って大きく曲 がる. したがって，A5083-O 板の場合，0.2\%耐力に近づ くに従って，応力一ひずタ関係の接線係数が低下寸るこ とが而何力に及ぼす影響の方が，残留応力が而荷力に及 ぼす影響より大きいために，残留応力が而荷力に及ぼす 影響が小さくなると推察される.

\section{（2）せん断耐荷力と縱横比の関係}

せん断耐荷力と縦横比の関係を図-19に示す。これは, A5083-Oの非接合板に対する結果である. 式(6)の初期た わ久を考慮し, $w_{0 \text { max }}=b / 250$ として, 長方形板の各縱横比 に対する座屈モード数を式(6)のmに使用している（図-4 参照）。図から分かるように，幅厚比パラメータの各值 に対して，せん断而荷力 $\tau_{l} / \tau_{02}$ の值はほぼ一定である。し
たがって，式(9)で定義される幅厚比パラメータRを用い ることにより, 前述の $\alpha=6.5$ の長方形板に対するせん断

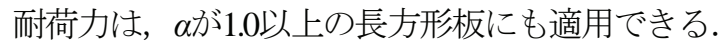

\section{6. 耐荷力曲線}

\section{（1） 耐荷力曲線の定式化}

A6061-T6，A6005C-T5，A5083-Oの $\tau_{/} / \tau_{02}-R$ 関係（また は $\tau_{l} / \tau_{j 02}-R_{j}$ 関係 $) \quad$ は, $\left.0.8<\tau_{l} / \tau_{02}<1.0 （ ま た は 0.8<\tau_{l} / \tau_{002}<1.0\right)$ で上向きの曲線， $0.8>\tau_{l} / \tau_{02}$ （または $0.8>\tau_{L} / \tau_{022}$ ）で下向きの 曲線になる．これを考慮して，面内せん断を受けるアル ミニウム長方形板の耐荷力曲線として，次式を採用する.

$$
\frac{\tau_{u}}{\tau_{p 0.2}}=\left\{\begin{array}{cc}
1 & \left(R_{p} \leq R_{c r}\right) \\
\frac{Q_{1}}{R_{p}}-\frac{Q_{2}}{R_{p}{ }^{2}} & \left(R_{c r}<R_{p}<R_{0.8}\right) \\
Q_{3}\left(\frac{R_{0.8}}{R_{p}}\right)^{Q_{4}} & \left(R_{0.8} \leq R_{p}\right)
\end{array}\right.
$$

$$
R_{p}=\frac{1}{\pi} \sqrt{\frac{12\left(1-\mu^{2}\right)}{k}} \sqrt{\frac{\tau_{p 0.2}}{E}} \frac{b}{t}
$$

ここに,

$\tau_{p 0.2}: \tau_{0.2}$ または $\tau_{j 02}$

$R_{p} \quad: \tau_{p 02}$ を用いた幅厚比パラメータ

$R_{a r}:$ 而荷力曲線が $\tau_{l} / \tau_{p 02}=1.0$ に交差する幅厚比パラ

$$
\text { メータ } R_{p} \text { の值 }
$$

$R_{0.8}: \tau_{\iota} / \tau_{002}=0.8$ に対する幅厚比パラメータ $R_{p}$ の值

$Q_{1}, Q_{2}, Q_{3}, Q_{4}$ : 定数

耐荷力曲線の区分と $R_{C}, R_{0.8}, Q_{1}, Q_{2}, Q_{3}, Q_{4}$ の值を 表-5に示す．同表には，アルミニウム合金と接合板の組 合せに対して， $\tau_{002}$ に使用される $\tau_{02}$ と $\tau_{002}$ の区別も示して ある. $Q_{1}, Q_{2}, Q_{3}, Q_{4}$ の值は, FEM解析值に式(12)の曲 線を仮定し，最小自乗法を適用することにより得られる 值である，耐荷力曲線の比較を図-20に示す，次に，耐 荷力曲線の区分の仕方について述べる.

A6061-T6の非接合板の耐荷力曲線には，図-7のm=5に 対する非接合板のFEM解析值を適用する.

A6061-T6 の端部接合板と，中央接合を有する端部接 合板に対して，図-11(a) と(c)の強度低下評価モデル $\mathrm{M} の$ FEM 解析值を適用する. A6061-T6 の中央接合板に対し て, 図-11(b)の強度低下評価モデル F の FEM 解析值を適 用する. 図-12 に示すように，A6061-T6 の中央増厚接合 板の耐荷力は非接合板の耐荷力を下回らないので，中央 増厚接合板の耐荷力に対して非接合板の耐荷力を適用寸 
表-5 耐荷力曲線の区分と

$R_{o r}, R_{0.8}, Q_{1}, Q_{2}, Q_{3}, Q_{4}$ の值

\begin{tabular}{|c||c|c|c|}
\hline アルミニウム合金 & $\begin{array}{c}\text { 非接合板 } \\
\text { 中央増厚接合板* }\end{array}$ & 中央接合を端部接合板 & 中央揣部接合板 \\
\hline \hline A6061-T6 & JA $\left(\tau_{0.2}\right)$ & JB $\left(\tau_{j 0.2}\right)$ & JC $\left(\tau_{j 0.2}\right)$ \\
\hline A6005C-T5 & JA & JB $\left(\tau_{0.2}\right)$ & \\
\hline A5083-O & \multicolumn{3}{|c}{} \\
\hline
\end{tabular}

* : 中央増厚接合板はA5083-Oに適用されない.

板幅の適用範囲 : 非接合板に対して制限なし

接合板に対して $400 \mathrm{~mm}$ 以上

\begin{tabular}{|c||c|c|c|c|c|c|}
\hline 記号 & $R c r$ & $R_{0.8}$ & $Q{ }$ & $Q^{2}$ & $Q{ }$ & $Q_{4}$ \\
\hline \hline JA & 0.60 & 1.09 & 1.20 & 0.36 & 0.80 & 0.81 \\
\hline JB & 0.53 & 0.92 & 1.02 & 0.26 & 0.80 & 0.76 \\
\hline JC & 0.56 & 0.96 & 1.06 & 0.28 & 0.80 & 0.73 \\
\hline
\end{tabular}

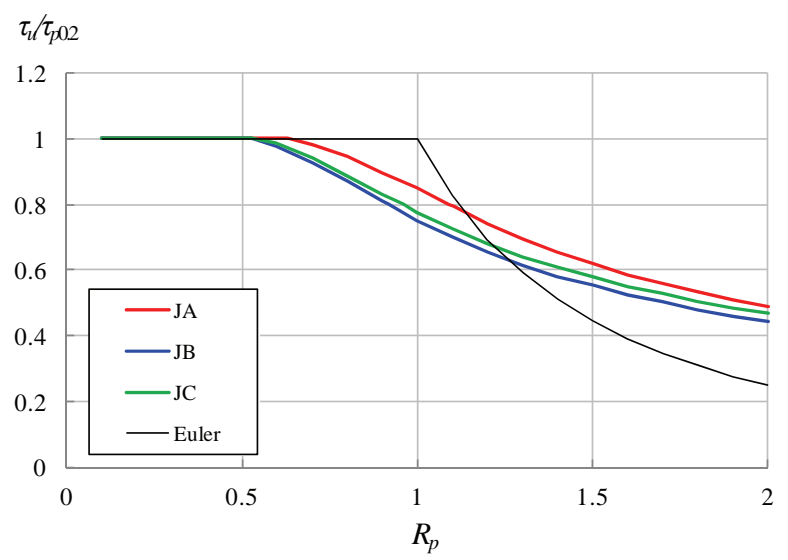

図-20 耐荷力曲線の比較

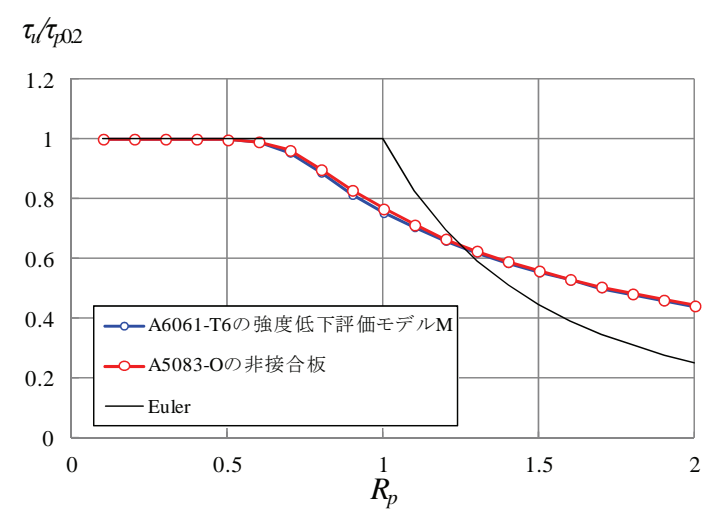

図-21 A6061-T6の強度低下評価モデル M の而荷力 と A5083-Oの非接合板のそれとの比較

る. 4 章(5)節で述べたように，A6061-T6 板と A6005C-T5 板の耐荷力はほぼ一致するので，両者の耐荷力区分は同 じにする.

図-17に示すように，A5083-Oのせん断耐荷力に接合位 置, 接合方法, 残留応力による影響は小さいので, A5083-Oのせん断耐荷力に対して, 非接合板のFEM解析 值を適用する．他方，図-21に示すように， $\tau_{l} / \tau_{p 0.2}$ と $R_{p}$ で

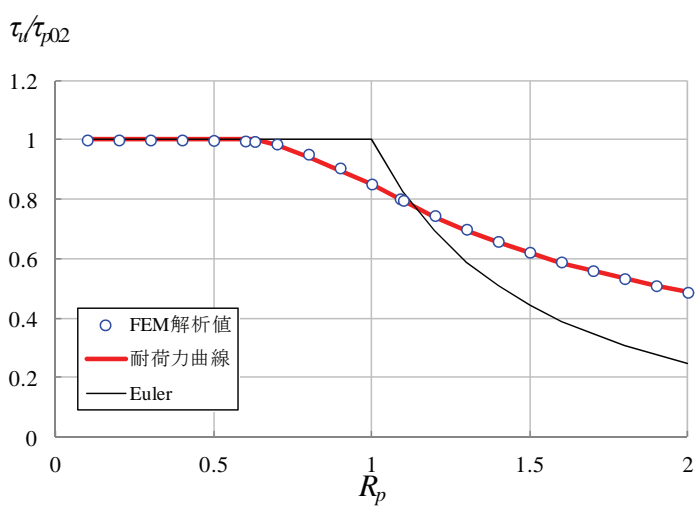

(a) JA

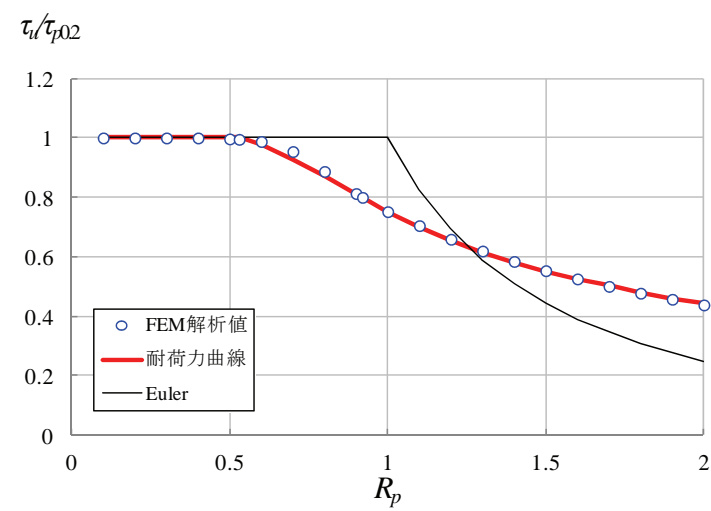

(b) $\mathrm{JB}$

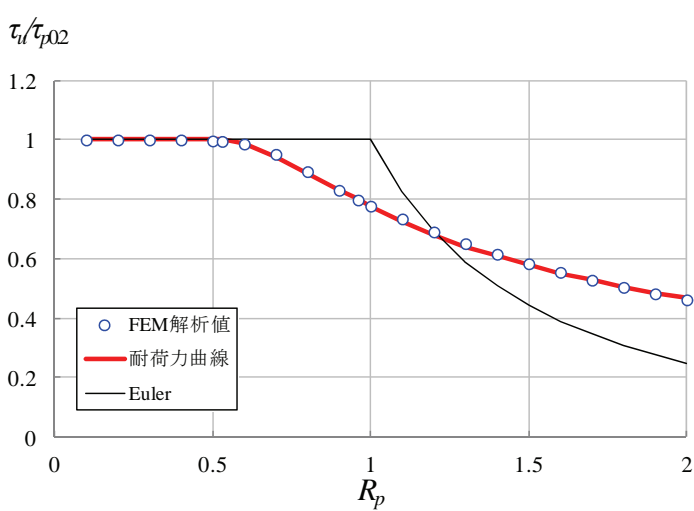

(c) JC

図-22 而荷力曲線と FEM解析值との比較

表されたA5083-Oの非接合板の耐荷力は，A6061-T6の強 度低下評価モデル $\mathrm{M}$ の耐荷力と一致する。これは，表-2 に示すように，両者のひずみ硬化パラメータの值は同じ であり，両者の $0.2 \%$ 耐力もお互いに近い值になるから である。したがって，A5083-Oの非接合板の耐荷力曲線 は, A6061-T6の端部接合板および中央接合を有する端部 接合板の耐荷力区分と同じにする.

接合板の解析は, 板幅が $400 \mathrm{~mm}$ と $800 \mathrm{~mm} に$ 限定されて いるが，6000系アルミニウム合金板に対しては4章(3)節， A5083-O板に対しては5章(1)節で述べたように，アルミ ニウム合金板においては，板幅が小さくなると，接合部 


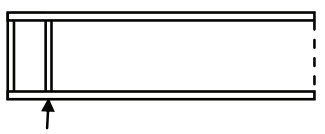

(a) 剛端支持 (ES1)

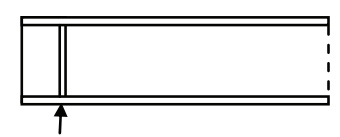

(b) 非剛端支持（ES2）
図-23 桁端の支持条件

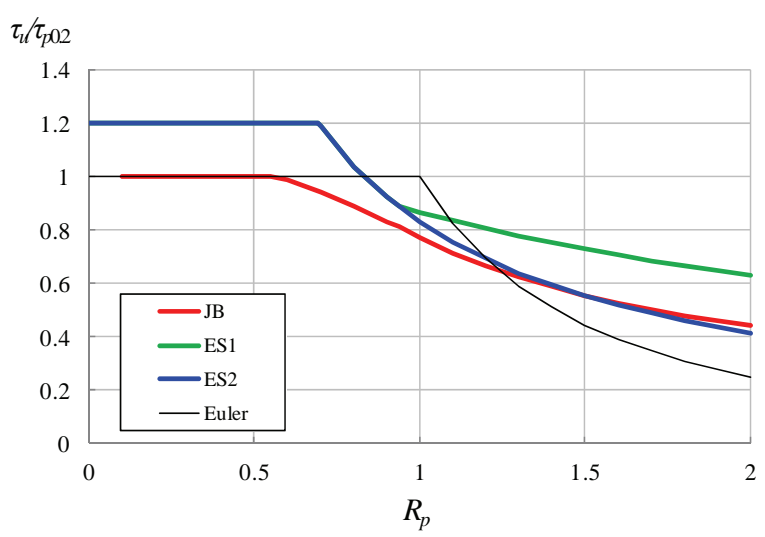

図-24 Eurocode9の耐荷力曲線との比較

の強度低下と残留応力がせん断而荷力に影響を与える.

したがって，表-5に示すように，接合板の板幅の適用範 囲を400mm以上としている. アルミニウム合金板の板幅 の上限は，製作上の制約等，他の条件から決められるこ とになるであろう。

式(12)が与える耐荷力曲線とFEM解析值との比較を図22に示寸. 式(12)の耐荷力曲線の上にFEM解析值が乗つ ている.

\section{（2）Eurocode 9の耐荷力曲線との比較}

図-23を参照して, Eurocode 994においては, 次の耐荷 力曲線が規定されている.

(a) 剛端支持（ES1）に対して,

$$
\frac{\tau_{u}}{\tau_{0.2}}=\left\{\begin{array}{cc}
\eta & (R \leq 0.83 / \eta) \\
\frac{0.83}{R} & (0.83 / \eta<R<0.937) \\
\frac{2.3}{1.66+R} & (0.937 \leq R)
\end{array}\right.
$$

(b) 非剛端支持 (ES2) に対して，

$$
\begin{aligned}
& \frac{\tau_{u}}{\tau_{0.2}}=\left\{\begin{array}{cc}
\eta & (R \leq 0.83 / \eta) \\
\frac{0.83}{R} & (0.83 / \eta<R)
\end{array}\right. \\
& \text { ここに, } \quad \eta=0.7+0.35 \frac{\sigma_{B}}{\sigma_{0.2}} \quad(\eta \leq 1.2) \\
& \sigma_{B}: \text { 引張強さ }
\end{aligned}
$$

式(14)と(15)は，MG溶接による端部接合板の而荷力曲
線に対応寸る. 本研究の耐荷力曲線J $\mathrm{B}$ Eurocode 9の耐 荷力曲線ES1［式(14)］およびES2［式(15)］の比較を図24に示す. Eurocode 9では，0.2\%耐力以上のひずみ硬化 を耐荷力に考慮しているので， $\tau_{u} / \tau_{002}$ が1を超える. 本研 究で採用した長方形板の両端における, 面内方向の境界 条件は, 図-23(b)の非剛端支持に対応する. 本研究では, $0.2 \%$ 耐力以上のひずみ硬化を考慮していないので，幅 厚比パラメータが約1.2以下の領域で, 而荷力曲線JBは 耐荷力曲線ES2より低いが，この幅厚比パラメータの值 より大きい領域では, 耐荷力曲線JB と而荷力曲線ES2は 互いに近い.

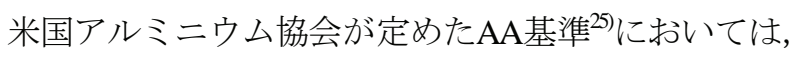
座屈強度が基準強度に採用されているため, 本研究の耐 荷力曲線との比較対象にならない.

\section{7. 結論}

本研究では, 面内せん断を受ける, 細長い長方形板の 而荷力を有限要素法による弾塑性有限変位解析によって 明らかにした，考慮したアルミニウム合金は，熱処理ア ルミニウム合金A6061-T6，A6005C-T5, 非熱処理アルミ ニウム合金A5083-Oである，主な結論は次の通りである.

(1) 長方形板の長さ方向に, 座屈モード数に等しい波数 の初期たわみを有する長方形板の耐荷力は, 幅厚比 パラメータR [式(9)参照 $]$ が0.7から 1.1 範囲で, 1 波の初期たわみを有する長方形板の耐荷力より幾分 低下寸る. 長方形板の板幅方向の初期たわみ波形に よって, 耐荷力は変化しない.

(2) 長方形板の長さ方向に1波の初期たわみに対して, 最大初期たわみの大きさが変化しても耐荷力は変わ らないが，座屈モード数に等しい波数を有する初期 たわみに対して，Rが0.6から 1.10 範囲で, 最大初期 たわみが大きくなると，而何力がわずかに低下する。

（3）A6061-T6の接合板では，残留応力が而荷力に及ぼす 影響は小さい. 端部接合板, 中央接合板, 中央接合 を有する端部接合板に対して, 強度低下評価モデル MまたはF［4章(3)節参照］の耐荷力が下限值を与え る. 中央増厚接合板に対して, 非接合板の耐荷力が 下限值を与える.

(4) 無次元表示された, A6061-T6板とA6005C-T5板の耐 荷力はほぼ一致する.

(5) A5083-O板において, 接合位置, 接合方法, 残留応 力が而荷力に及ぼす影響は小さい.

（6）本研究の成果に基づいて，耐荷力曲線を式(12)で, 耐荷力曲線の区分を表-5で与えた.

今後, アルミニウム合金妳の耐荷力試験を実施し, 得 られた試験結果により，本論文で与えられた耐荷力曲線 
の妥当性を検証しなければならない.

謝辞 : 本研究に対して貴重な助言をいただきました，鋼 構造委員会アルミニウム合金材の鋼橋への適用検討小委 員会の委員各位に感謝の意を表します。

\section{参考文献}

1) 鋼構造委員会 : 21 世紀の建設材料 アルミニウム合金 の可能性, 土木学会, 平成 22 年度全国大会研究討論 会, 研 -06 資料, 2010.

2) アルミニウム橋研究会 : 蒲原ケミカル橋. http://alst.jp /str/bridge/kanbara.htm

3) 日本道路協会 : 道路橋示方書 - 同解説 I 共通編 II 鋼 橋編, 2012.

4) 日本道路協会：立体横断施設技術基準 - 同解説， 1979.

5) 日本アルミニウム協会(旧軽金属協会)：アルミニウム 合金土木構造物設計・製作指針案（第 1 次改訂試 案），1998.

6) 大倉一郎, 萩澤亘保, 花崎昌幸 : アルミニウム構造 学入門, 東洋書店, 2006.

7) 日本アルミニウム協会 土木構造物委員会 : アルミニ ウム合金土木構造物の摩擦摚拌接合部の品質検査ガ イドライン，2010年 9 月版, 2010.

8）大倉一郎, 北村幸嗣, 赤碕圭輔, 卯瀧高久, ビッ グ・ラズロ・ゲルゲリ, 三河克己：新しいアルミニ ウム合金製補剛桁の提案，構造工学論文集，Vol.51A， pp.203-210, 2005.

9) 大倉一郎, 小笠原康二：接合位置を考慮したアルミ 二ウム合金板の圧縮耐荷力, 構造工学論文集, Vol.56A, pp.111-121， 2010.

10) 大倉一郎, 小笠原康二：接合位置と板幅がアルミニ ウム合金板の曲げ耐荷力に与える影響，土木学会論 文集 A1（構造・地震工学）, Vol.68, No.2, pp.287299, 2012.

11）大倉一郎，小笠原康二：アルミニウム合金製自由突 出板の圧縮耐荷力, ALST 研究レポート, No.12, 2009. http://alst.jp/pdf/ALST_report12.pdf
12）奈良敬, 出口恭司, 福本唀士 : 純せん断応力を受け る鋼板の極限強度特性に関寸る研究, 土木学会論文 集, No.392/I-9, pp.265-271, 1988.

13) Kuranishi, S., Nakazawa, M. and Iwakuma, T.: A new formula to predict the ultimate shear strength of a plate girder, Japan Society of Civil Engineers, Structural Eng./Earthquake Eng., Vol.6, No.2, pp.239s-250s, 1989.

14) 葛西昭, 渡辺智彦, 宇佐美勉, Praween Chusilp : せん 断を受ける無補剛箱形断面部材の強度と変形能, 土 木学会論文集, No.703/I-59, pp.129-140, 2002.

15) 小川靖之, 藤井堅, 中村秀治 : 垂直補剛材を考慮し たプレートガーダーの終局強度相関曲線の提案，土 木学会論文集 A, Vol.63, No.2, pp.356-373, 2007.

16) 寺川勝大, 大倉一郎：面内せん断を受けるアルミニ ウム長方形板の耐荷力, ALST 研究レポート, No.23, 2012. http://alst.jp/pdf/ALST_report23.pdf

17) 日本マーク : MARC, K6, 2005.

18) Timoshenko, S. P. and Gere, J. M.: Theory of Elastic Stability, McGraw-Hill, pp.382-383, 1963.

19) 大倉一郎, 長尾隆史, 石川敏之, 萩澤亘保, 大隅心 平 : 構造用アルミニウム合金の応力ーひずみ関係お よび接合によって発生する残留応力の定式化，土木 学会論文集 A, Vol.64, No.4, pp.789-805, 2008.

20) Sharp, M. L.: Behavior and Design of Aluminum Structures, McGraw-Hill, 1993.

21) Mazzolani, F. M.: Aluminum Alloy Structures, Second edition, E \& FN Spon, 1995.

22) 大倉一郎, 佐藤純：摩擦摚拌接合を考慮した突起付 きアルミニウム合金板の提案, ALST 研究レポート, No.11, 2009. http://alst.jp/pdf/ALST_report11.pdf

23) 土木学会 鋼構造委員会 座屈設計ガイドライン改訂小 委員会 : 座屈設計ガイドライン［2005 年改定版］， 土木学会, 丸善, 2005.

24) Eurocode 9: Design of Aluminum Structures - Part 1-1: General structural rules, EN1999-1-1, 2007.

25) The Aluminum Association: Specifications for Aluminum Structures, 2010.

(2012. 9. 24 受付)

\section{ULTIMATE STRENGTH OF ALUMINUM ALLOY RECTANGULAR PLATES IN SHEAR}

\section{Ichiro OKURA and Masahiro TERAKAWA}

The ultimate strength of aluminum alloy plates in in-plane shear is investigated by the elastic-plastic large deflection analysis with FEM. The aluminum alloys taken into account are heat-treated alloys A6061-T6 and A6005C-T5 and non-heat-treated alloy A5083-O. The residual stresses and initial deflection caused by joining and the strength-reduction at joints in heat-treated 6000 alloys are considered in the analysis. It is shown that the upper limit of the ultimate strength of rectangular plates with joints of heattreated 6000 alloys is the $0.2 \%$ shear proof stress of the joints. Based on the results of the analysis, the ultimate strength curves are provided for rectangular plates in in-plane shear. 